BARTOSZ KUŁAN

School of Criminology and Penitentiary Science in Warsaw, Poland

\title{
The Junior Republic of William Reuben George (1866-1936) as an example of work with socially maladjusted young people in the United States
}

\begin{abstract}
Bartosz Kułan, The Junior Republic of William Reuben George (1866-1936) as an example of work with socially maladjusted young people in the United States. Interdisciplinary Contexts of Special Pedagogy, no. 31, Poznań 2020. Pp. 339-359. Adam Mickiewicz University Press. ISSN 2300-391X. e-ISSN 2658-283X. DOI: https://doi. org/10.14746/ikps.2020.31.16

This paper presents the assumptions put into practice by William Reuben George in the Junior Republic in the State of New York. The person of the founder of this pedagogical solution has not yet been widely known in Polish literature. The assumptions introduced in the Junior Republic were part of the so-called progressive approach in working with juvenile offenders in the United States. The paper presents the main assumptions used in working with young people, the idea of the Junior Republic and the daily activities of minors. The paper is concluded with a summary.
\end{abstract}

KEY WORDS: Junior Republic, juvenile offenders, William Ruben George, Freeville 


\title{
1. Introduction
}

\begin{abstract}
The history of work with juvenile offenders and methods of their social rehabilitation have been the subject-matter of many studies. ${ }^{1}$ The researchers of the issue dealt with the topic of work
\end{abstract}

${ }^{1}$ For more about historical reflections concerning the problem of minors both in Poland and in the USA See: E.J. Dukaczewski, A historical outline of the development of the care of a socially maladjusted child (juvenile offender) in Poland until the outbreak of World War II (Rys historyczny rozwoju opieki nad dzieckiem niedostosowanym społecznie (przestępczym) w Polsce do wybuchu II wojny światowej), [in:] The social rehabilitation of minors. Experiences and conceptions (Resocjalizacja nieletnich. Doświadczenia i koncepcje), ed. K. Pospiszył, Warszawa 1990, pp. 173-207; J.A. Mazur, Care and social rehabilitation towards juvenile delinquency in the interwar period on the example of Lublin (Opieka i resocjalizacja wobec przestępczości nieletnich w okresie międzywojennym na przykładzie Lublina), Kraków 2017, p. 325; A. Mogilnicki, The child and crime (Dziecko i przestępstwo), Warszawa 1925, p. 425; Juvenile delinquency: theory and practice (Przestępczość nieletnich - teoria i praktyka), ed. S. Ćmiel, Józefów 2011, p. 632; D. Raś, On the improvement of culprits in prisons and juvenile institutions $(O$ poprawie winowajców w więzieniach i zakładach dla nieletnich), Katowice 2006, pp. 49-65, 105-146, 181-191; B. Kułan, Education as a type of social rehabilitation of juvenile offenders in the Second Polish Republic (Edukacja jako forma resocjalizacji nieletnich przestępców w II Rzeczypospolitej, [in:] Selected areas of child upbringing and education from a historical perspective (Wybrane obszary wychowania i edukacji dziecka w ujeciu historycznym), ed. B.A. Orłowska, B.M. Uchto-Żywica, K. Prętki, Gorzów Wielkopolski 2019, pp. 165-180; Z. Bugajski, The minor in the light of valid penal acts in Poland (Nieletni w świetle obowiazujących ustaw karnych w Polsce), "W Służbie Penitencjarnej”, 1936, no. 3, pp. 5-6; H. Fish, Our prison system for minors (Nasze więziennictwo dla nieletnic), "Przegląd Więziennictwa Polskiego", 1935, no. 2, pp. 5-7; A. Golus, Wreckers, stocks, shackles, or how youth was reformed: social history (Plagi, dyby, kajdany, czyli jak naprawiano młodzież: historia społeczna), "Ale historia”, 2017, no. 35, pp. 4-5; M. Grzegorzewska, The upbringing of juvenile offenders (Wychowanie nieletnich przestępców), "Przegląd Więziennictwa Polskiego", 1929, no. 10, pp. 2-3; A. Kołakowski, The issues of juvenile delinquency in interwar Poland in "Przegląd Więziennictwa Polskiego" (Problematyka przestępczości nieletnich w międzywojennej Polsce na łamach "Przegladu Więziennictwa Polskiego"), Research Papers of the Jan Długosz Academy in Częstochowa (Prace Naukowe Akademii im. Jana Długosza w Częstochowie), 2017, v. 26, no. 2, pp. 317-333; E. Neymark, Juvenile offenders in Poland (Nieletni przestępcy w Polsce), "Gazeta Administracji i Policji Państwowej", 1924, no. 11, pp. 1006-1008; S. Sokołowski, Correctional facilities for minors (Zakłady poprawcze dla nieletnich), "Przegląd Więziennictwa Polskiego", 1933, no. 1, pp. 5-8. 
with minors both from a practical and theoretical perspective. The first attempts to regulate the subject of juvenile offenders comprehensively in Poland date back to the Second Polish Republic. Along with the restoration of independence, the interest in Western ideas concerning the social rehabilitation of socially maladjusted young people also increased. Polish researchers analysed also American conceptions, which proved very interesting because of numerous experiments. ${ }^{2}$ On that ground, the first papers describing the person of William Reuben George - the founder of the Junior Republic in the State of New York ${ }^{3}$ - were published in interwar Poland. One of the first persons who undertook that topic was Zygmunt Bugajski ${ }^{4}$ -

2 The interest in American solutions concerning work with juvenile offenders was popular among Polish researchers both in the interwar period and after World War II. From among the most important works dealing with these issues, note the following: See: S. Baley, The issue of fight against juvenile delinquency in the context of contemporary experience in the United States of Northern America (Zagadnienie walki $z$ przestępczościa młodocianych na tle wspótczesnych doświadczen w Stanach Zjednoczonych Ameryki Pótnocnej), Warszawa 1948, p. 63; A. Barczykowska, S. Dzierzyńska-Brześ, M. Muskała, The rehabilitative impact system of England and the United States of America (System oddziatywań resocjalizacyjnych Anglii i Stanów Zjednoczonych Ameryki), Poznań 2016, p. 327; C. Czapów, Will Johnny become a gangster? Remarks on methods of fight against juvenile delinquency (Czy Johnny stanie sie gangsterem. Uwagi o metodach walki z przestępczością młodzieży), Warszawa 1959, p. 187; A. Barczykowska, S. Dzierzyńska-Breś, The social rehabilitation of minors in the United States of America (Resocjalizacja nieletnich w Stanach Zjednoczonych Ameryki), "Resocjalizacja Polska" 2015, no. 9, pp. 27-42.

${ }^{3}$ See: Z. Bugajski, The Junior Republic (Republika dziecięca), "W Służbie Penitencjarnej" 1936, no. 14, pp. 7-9.

${ }^{4}$ Zygmunt Bugajski (1887-1940), a Polish lawyer and penitentiary expert. He was born in Dąbrowa Górnicza on $6^{\text {th }}$ December 1887. As a young man, he engaged in the activity of the Polish Socialist Party - Revolutionary Faction. He took part in a school strike during the 1905 Revolution. Upon graduation from the Faculty of Law at the University of Moscow, he took up work in an institute for juvenile offenders. When the Bolsheviks came into power, he fled from Russia to avoid being arrested. He arrived in Poland in November 1918 and started working in the Ministry of Justice and later in the prison system. He was, among others, the warden in Mokotów and Pawiak prisons. In 1921, he returned to work in the Ministry of Justice and took part in the creation of the most important legal acts regarding the 
a lawyer, a penitentiary expert and the creator of the Polish penitentiary system in 1918-1939. Apart from Z. Bugajski's works, it is impossible to find a broader reception of W.R. George's views in Polish scientific discourse. ${ }^{5}$ Polish literature concerning the problem of juvenile delinquency from a nationwide perspective, i.e., the entire United States, looked slightly different. This topic was brought up both before and after World War II. From among outstanding minds of Polish pedagogy, this subject was handled, among others, by Stefan Baley6, or Czesław Czapów.7 In modern times, these issues have been analysed, among others, by Agnieszka Barczykowska and Sonia Dzierzyńska-Breś. ${ }^{8}$ Judging from the above, we can

Polish prison system. In September 1939, he was evacuated with employees of the Ministry of Justice to the Dubno-Kovel raion. Arrested by the NKVD, he was sent to the POW camp in Kozelsk. He was killed in Katyn in the spring of 1940. The text is based on: B. Kułan, An unknown victim of Katyn. Zygmunt Bugajski (1887-1940), a lawyer and penitentiary expert (Nieznana ofiara Katynia. Zygmunt Bugajski (1887-1940) prawnik i penitencjarysta), Kraków 2018, p. 394.

${ }^{5}$ One of the more important works in English regarding W.R. George's Junior Republic is a book by J.M. Holl. See: J.M. Holl, Juvenile reform in the progressive era: Wiliam R. George and the Junior Republic movement, Ithaca 1971, p. 348.

${ }^{6}$ Stefan Baley (1885-1952) a Polish psychologist, doctor and pedagogue. He graduated from the University of Lviv; he also studied in Paris, Berlin and Warsaw. Then he worked as a doctor in a psychiatric hospital in Lviv. In 1928, he returned to Warsaw and took up work at the local university and in the Central Institute of Physical Education and Sport. He specialised mainly in juvenile education. He died in 1952. The text is based on: E. Kosnarewicz, Stefan Baley, [in:] A dictionary of Polish psychologists (Stownik psychologów polskich), ed. T. Rzepa, R. Stachowski, Poznań 1992, pp. 19-21.

${ }^{7}$ Czesław Czapów (1925-1980), a Polish researcher, lecturer at the University of Warsaw, called the founder of the Warsaw social rehabilitation school. He was born in Grodno. He was a Home Army soldier and a repressed person in the times of the People's Republic of Poland. He wrote many works in the field of rehabilitative pedagogy. The text is based on: W. Kaczyńska, Czestaw Czapów 1925-1980. A testimony of three generations (Czestaw Czapów 1925-1980. Świadectwo trzech pokoleń, Warszawa 2003, p. 474.

8 See: A. Barczykowska, S. Dzierzyńska-Brześ, M. Muskała, The rehabilitative impact system... (System oddziatywań resocjalizacyjnych...), p. 327; A. Barczykowska, S. Dzierzyńska-Breś, The social rehabilitation of minors in the United States of America... (Resocjalizacja nieletnich w Stanach Zjednoczonych Ameryki...), pp. 27-42. 
say that a more detailed presentation of very interesting views of W.R. George and the history of the Junior Republic may serve as a supplement to the research done so far.

\section{A description of work with socially maladjusted young people in the United States}

The United States wrote a glorious chapter in the field of work with delinquent offenders. It was there that the first penitentiary system (called the separate system), assuming the reform of prisoners through rehabilitative impact, came into being. It was established in Philadelphia by Protestant Quakers. ${ }^{9}$ Historically speaking, the United States and their system of fight with juvenile delinquency was strongly influenced by English thought. Thus, it is hardly surprising that views of such thinkers as John Locke ${ }^{10}$ or William Blackstone ${ }^{11}$, who jointly referred to children as beings who should

${ }^{9}$ Quakers - a Protestant sect having its roots in Puritanism. It was relatively popular among American settlers coming from England. They are credited with the creation of the first imprisonment system (called the progressive system). They thought that a convict should be covered by the scope of rehabilitative work through reading of the Bible, labour and compulsory total silence. This system, although far from ideal, was the first form of programmatic impact on imprisoned persons. The text is based on: S. Walczak, Penitentiary law [Prawo penitencjarne], Warszawa 1972, pp. 109-113; H. Popławski, Penitentiary Law [Prawo Penitencjarne], Gdańsk 1984, pp. 146-148.

10 John Locke (1632-1704), an outstanding English philosopher, one of the most important representatives of empiricism and liberalism. A member of the British Royal Society. Forced to leave England, he returned there only after the fall of the Stuart family and the Glorious Revolution. His output included many philosophical treatises that had a huge influence on subsequent philosophy. The text is based on: John Locke Prophet of Common Sense, New York 1967, pp. 138-140.

11 William Blackstone (1723-1780), an English lawyer and philosopher. He studied at Oxford University and then practised the profession of lawyer. He specialised mainly in English law. He was a deputy of the British Parliament. He opposed the demands of American colonists willing to gain independence. He died in 1780. The text is based on: W. Blackstone, Law and Letters in the Eighteenth Century, Oxford 2008, pp. 1-12. 
bear responsibility for their acts, prevailed in North America before the emergence of an independent state. Only a few dozen years later, in 1820 and 1830, were the issues concerning minors regulated in the USA. Also at that time, convicted minors were separated from adults, and the first houses of correction were established. These institutions were divided into those for neglected children and those for the children who have already committed an offence. The principle of indefinite sentences was also applied, i.e., the punishment was served until the child improved or reached the age of 21 years. An important factor was also the introduction of the Parens Patria idea, where parenting responsibilities were taken over by the state. Another significant problem was the institutional subordination of American correctional facilities. Sometimes they remained in private hands, where children were often used for slave labour and kept in conditions that were very similar to the prison ones. A contradiction of such facilities was W.R. George's Freeville, which became popular not only in America at the turn of the 20th century. It is worth emphasising that the founder of the Junior Republic was a merchant by education and never dealt with pedagogical thought; everything he used in his facility was based only on the observation of social life. At this point, it is worth presenting a brief summary of W. R. George's life and describe his life experiences that influenced the subsequent character of actions conducted in the Junior Republic. ${ }^{12}$

\section{William Reuben George and his Junior Republic}

W.R. George was born on a farm close to West Dryden in the State of New York on ${ }^{13} 4^{\text {th }}$ June 1866 . He spent his childhood away from the urban bustle; as he recollected: 'I had a merry time of it,

12 W.R. George, The Junior Republic History and Ideals, New York 1910, p. 2.

13 See: C.R. Reynolds, E. Fletcher-Janzen, Concise Encyclopedia of Special Education, New York 2002, p. 429. Cf: Funk \& Wagnalls Standard Encyclopedia of the Wolrd's Knowledge, New York 1912, p. 60. 
reading books, roaming the fields and killing imaginary Indians with wooden guns. ${ }^{14}$ 'When he was 14 years' old, his parents moved to New York. In spite of the change of their residence, they frequently returned to their old village house. Being brought up on the farm and recognising the benefits of living in the countryside had a strong impact on the subsequent rules that W.R. George followed in his work with socially maladjusted young people. Ideas such as work close to nature, staying in the open air or learning the world through empirical experience emerged as a result of his personal experiences. ${ }^{15}$ Before establishing the Junior Republic, however, the hero of this paper did various odd jobs. In the initial period of his adult life, he mainly engaged in trade. Staying in New York most of the time, he could observe the American society living in this large metropolis. In this way, he became familiar both with the mentality of persons living in cities and capitalism with its benefits and shortcomings. At this stage, W.G. George was mainly interested in the fate of children. He started paying the biggest attention to the most neglected children that roamed around the streets of New York. ${ }^{16}$ Concerned with their fate, he started working with children of the street in the most impoverished districts of New York along with the local Protestant Church. ${ }^{17} \mathrm{He}$ also decided to organise various forms of recreation away from the city for this type of youth. In 1890, he gained financial support from the Fresh Air

14 W.R. George, The Junior Republic History and Ideals..., p. 2.

15 Ideas of this kind were not isolated. Previously, they could be found, for instance, in J.J. Rousseau's works. These works contained numerous references to bringing children up through contact with nature. This was reflected, e.g., in the famous book Emile, or On Education. The author of the work, however, was far from the practical implementation of the presented principles. He put his children in an orphanage, refusing to take care of them. See: J.J. Rousseau, Emile, or On Education, v. 1-2, Polish translation: Emil - czyli o wychowaniu, Warszawa 1955, pp. 280, 453. Cf: S.E. Zawadzka, Jan Jakub Rousseau, Warszawa 2009, p. 324.

16 W. Hull, The George Junior Republic, "Annals of the American Academy of Political and Social Science", 1897, v. 10, p. 73.

17 See: C.R. Reynolds, E. Fletcher-Janzen, Concise Encyclopedia of Special Education..., p. 429. 
Foundation 18 , which allowed him to organise the first recreational camp for children from poor families. ${ }^{19}$ Most of the first participants of this camp came from circles of W.R. George's friends. He decided to organise a trip for the children whose parents did not earn as much as he did. He chose Freeville as the location of the first camp; it is a village with a small railway station situated close to the rural house where he grew up. ${ }^{20}$ The first trip organised for children from poor families was fully successful. During the subsequent few years, it was followed by other camps, but most of the children treated them as holidays and returned to New York after the end of them. W.R. George was somewhat disappointed with this form of recreation, because he had already thought of creating the "Junior Republic" for juvenile offenders and children of the street. His new idea was also financed by the Fresh Air Foundation. W.R. George was not able to finance the entire project. ${ }^{21} \mathrm{He}$ used the obtained funds for buying, e.g., tools necessary for work. However, because of the misbehaviour and large number of "children of the street" who took part in the first camp, W.R. George started reconsidering the sense of existence of the facility. In spite of the whole enthusiasm, pupils sometimes destroyed tools on purpose, stole them or sold them in the city. ${ }^{22}$ Because of such behaviours, the founder of Freeville decided to close the facility. However, he suspended this decision for a year, wanting to complete farm works under way. At that time, William George hit upon the idea that not only saved his

18 Fresh Air Foundation - an organisation founded in 1877. Its aim is bring help to children from poor families and to organise holidays and summer camps for them. See: website of The Fresh Air Fund https://freshair.org/learn-about-us/ (access: $4^{\text {th }}$ June 2020).

${ }^{19}$ For more about the role of the Fresh Air Foundation in the creation of the Junior Republic, see: J.M. Holl, Juvenile reform in the progressive era..., pp. 83-85.

20 W.R. George, Nothing Without Labor: being the motto of the Gorge Junior Republic located at Freeville New York, New York 1922, p. 30.

21 At a later time, the Junior Republic was financed, e.g., from charity donations, contributions from parents of children staying in Freeville and from sales of products created by pupils of the Junior Republic. See: Ibidem, p. 42.

22 W.R. George, The Junior Republic - history and ideals, New York, 1910, pp. 24-25. 
facility, but also changed its future. Seeing that his pupils did not understand the sense of labour, because they received food, accommodation and clothing regardless of its amount, he decided to deprive them of all comforts, leaving only farm tools at their disposal. The pupils initially rebelled and refused to work, but their resistance was broken after two days without clothing and food. As a consequence of this, they started appreciating labour and its products. After a few days, the pupils requested W.R. George to create an institution in the village that would protect their private property and the resources that they had managed to work out. This gave rise to the motto of William George's Junior Republic: 'nothing without labour'. ${ }^{23}$ The first stay of minors from the lower social classes ended in Freeville in the autumn of 1894. The young people returned to New York, not only repaying the costs of the ticket and tools destroyed during the strike, but also with savings earned on the farm. ${ }^{24}$ The success of the first camp reinforced W.R. George's belief in the effectiveness of the new approach and the usefulness of this kind of institution. In July 1895, another camp for minors took place. ${ }^{25} 144$ children took part in it. W.R. George's activity started to attract the attention of the New York press, which usually expressed favourable opinions on his work. ${ }^{26}$

In subsequent years, W.R. George, called "Daddy" by his pupils27, modernised the system established in Freeville. Children arriving at the Junior Republic were divided into three categories. The primary aim was to prevent the dominance of specific groups of minors. The first group consisted of children from good homes and from families getting by in the society. They could spend their time

${ }^{23}$ W.R. George, Nothing Without Labor..., p. 5.

24 The first summer camp was organised by W.R. George in 1890-1895. Only later did they assume a permanent form known as the Junior Republic. See: W. Hull, The George Junior Republic..., p. 73.

25 W.R. George, L.B. Stowe, Citizens Made and Remade, New York-Boston, 1912, p. 65.

26 W.R. George, Nothing Without Labor..., p. 32.

${ }^{27}$ Idem, The Junior Republic..., p. 8. 
in the Junior Republic by continuing their education or completing school internships. They constituted the healthy social tissue that showed others how to do the right thing. The second group included girls who were not demoralised and had been sent to the Junior Republic by associations protecting young girls. A stay in Freeville was supposed to help minors obtain education and learn a wellpaid profession. Actions of this kind protected girls against dangers such as the prostitution of minors. The third group comprised boys with severe sentences. It was the largest and subject to special control. The main emphasis was laid on rehabilitating the minors who have entered the criminal path and restoring them to the society. ${ }^{28}$ However, as W.R. George emphasised, each minor crossing the threshold of the Junior Republic had a clean sheet and was treated as a "carte blanche". ${ }^{29}$

W. R. George's Freeville was organised according to Republican principles that prepared pupils very well to cope in the American reality. Thus, a system of principles and rules called the Constitution of the Junior Republic ${ }^{30}$ was established, actually corresponding to the political system of some democratic states. It is worth noting that the Montesquieu tri-partite division of power functioned quite efficiently in the Junior Republic. ${ }^{31}$ Citizens of this youth quasi-state were children of both sexes at the age of 16 to 21 years. $^{32}$ They had electoral rights that allowed them to elect

${ }^{28}$ Idem, Nothing Without Labor..., p. 19.

${ }^{29}$ Ibidem, p. 21.

30 The text of the Constitution and laws prevailing in the Junior Republic was published. See: Constitution and the General Laws of the George Junior Republic Freeville N.Y., New York 1922, p. 62.

31 The traditional division of power into the judiciary, legislative and executive power in democratic systems, proposed by Charles Montesquieu. See: C. Montesquieu, Spirit of the Laws, Polish translation: O duchu praw, Warszawa 2009, pp. 14-15.

32 It is worth stressing that the Junior Republic was founded in 1890 and awarded electoral rights both to minor boys and girls right from the beginning. This did not occur without certain disputes. In juxtaposition with this fact, it must be stated that American women obtained electoral women only in 1920, and the situation was changed by the amendment no. 19 to the constitution. The first state that introduced 
a president and their representatives in the two-house parliament. ${ }^{33}$ The congress convened in this way was the only legislative body in the Junior Republic and established the laws that all pupils had to observe. The most important competences of the parliament included, among others, the regulation of internal life in Freeville, economic issues, the election of authorities, specifying the obligations of young citizens and a system of punishment of defiant inhabitants of the Junior Republic. ${ }^{34}$ The executive power was exercised by the president elected by pupils. This function was initially held by W.R. George, but later he handed over his competences to the inhabitants of Freeville. ${ }^{35}$ The judiciary power was held by a jury consisting of pupils. If the culprit was caught red-handed, he was put in prison until the session of the court. The trial took place with the participation of the prosecutor and the defence attorney. The person suspected of the offence chose a barrister. The judgement was passed by the presiding judge upon consultation with the jury. ${ }^{36}$ The children initially found it difficult to learn legal procedures, so necessary help was provided by students of law, who arrived in the Junior Republic as a part of their internship. Later, these responsibilities were taken over by minors themselves. ${ }^{37}$ After the judgement had been passed, the pupil was imprisoned. A large cage was adapted to this purpose; the convict stayed there all night. During the day, he worked with other children and performed normal du-

electoral rights of women was Wyoming in 1869. See: J. Adams, Woman $\mathcal{E}$ The Vote A World History, Oxford 2014, p. 515. Cf: W.R. George, Nothing Without Labor..., p. 30. Cf: W. Hull, The George Junior Republic..., p. 74.

33 T. Roosevelt, The George Junior Republic, "The Outlook", 1912, v. 100, p. 118.

34 Z. Bugajski, The Junior Republic... (Republika dziecięca...), p. 8.

35 For more about the powers of the president and the vice-president in the Junior Republic and other functions held by minors, see: W.R. George, The Junior Republic..., pp. 251-286. Cf: W.R. George, L.B. Stowe, Citizens Made and Remade..., p. 105.

36 W. Hull, The George Junior Republic..., pp. 148-149.

${ }^{37}$ It is interesting to note that, according to W.R. George's idea, the judgement was passed by pupils themselves - the convict's colleagues. Sometimes children were concerned so much about the verdict announced by their colleagues that suicide attempts occurred. 
ties. However, he had to wear a striped jacket that set him apart from others. ${ }^{38}$ As a part of restrictions, the "convict" was not remunerated for his work. ${ }^{39}$ The prison guards were mainly boys. Apart from supervision, they had to treat convicts without compassion so that the prisoner would feel the horror of the punishment. A separate arrest was designated for girls; they served their punishments in milder conditions because it was said that they should be 'punished more leniently because of their more delicate nature'. ${ }^{40}$

In the justice system of the Junior Republic, a very important role was played by the police, which also consisted of pupils. ${ }^{41}$ Initially, many children were willing to perform this service due to its lucrativeness and the opportunity to earn extra funds. Because of this, special examinations were introduced for candidates, who had to prove their physical strength and intellectual capacity. Upon fulfilment of these requirements, a young citizen of the Junior Republic received a uniform and a police badge. However, he had to comply with the rules and the official hierarchy applicable in this force..$^{42}$ The truly democratic system of the Junior Republic was liked very much by the President of the United States Theodore Roosevelt ${ }^{43}$, who visited Freeville in 1912. In an article published in the press, he wrote: 'Mr. George's theory is that any boy or girl, man or woman, of sufficient strength of character can by practical experience as

${ }^{38}$ W. Hull, The George Junior Republic..., p. 77.

${ }^{39}$ Z. Bugajski, The Junior Republic... (Republika dziecięca...), p. 8.

${ }^{40}$ T. Roosevelt, The George Junior Republic..., p. 118.

${ }^{41}$ For more about the police's activity in the Junior Republic, see: W.R. George, The Junior Republic..., p. 8.

${ }^{42}$ W.R. George, Nothing Without Labor ..., p. 17.

${ }^{43}$ Theodore Roosevelt (1858-1919) - an American politician, the president of the United States, a laureate of the Nobel Peace Prize. He was born in New York. He graduated from Harvard University. Later he engaged in a political career. He suspended it only for the time of the American-Spanish War, in which he fought as a cavalryman. After the assassination of William McKinley by a person of Polish descent, T. Roosevelt was elected president of the USA. He held this function until 1901. He died in 1919. The text is based on: M.R. Canfield, Roosevelt in The Field, Chicago 2015, p. 475; E. Morris, The Rise of Theodore Roosevelt, Chicago 2001, p. 920. 
a responsible and independent citizen be taught, or, to speak more accurately, teach himself or herself, that good citizenship is the only kind of citizenship worth having, even from the individual's own standpoint' ${ }^{4}$

Other very important factors of the functioning of the Junior Republic were the conditions of stay in Freeville and minors' daily activities. All children without exception were bound by the principle that they had to obtain all necessary items with their own work. This was consistent with W.R. George's principle and resulted in the payment of accommodation costs and other expenses from one's own funds. ${ }^{45}$ It is worth noting that young people used their own currency in all transactions; it was made of aluminium disks and served as tender in the Junior Republic. ${ }^{46}$ If pupils were in default with payments, e.g., for their accommodation, they were deprived of it. In such a case, they received the status of a vagrant and were put in arrest for the night or punished. ${ }^{47}$ In the case of some works, such actions were regarded as excessively brutal, but, as T. Roosevelt noted down: 'No boy is forced to work; but if he does not choose to work, then he does not eat! It occasionally takes him some days to realize that this is a fact and not an abstract theory with which he is confronted; but he is taught the fact by actual hunger, and then he goes to work' ${ }^{48}$

Minors in the Junior Republic were accommodated in wooden houses spread out across Freeville. Part of the buildings was intended for girls, and the other part for boys. In each hotel, there was an adult woman responsible for the supervision of minors. ${ }^{49}$ She was the "guardian" of good manners; as W.R. George said, she was

44 T. Roosevelt, The George Junior Republic..., p. 117.

${ }^{45}$ In the Junior Republic, a special currency created for the needs of pupils was used for payments. These were metal disks of different values, by means of which minors paid for their needs. See: Z. Bugajski, The Junior Republic... (Republika dziecięca...), p. 9.

46 W.R. George, Nothing Without Labor..., p. 6.

47 Z. Bugajski, The Junior Republic... (Republika dziecięca...), p. 9.

48 T. Roosevelt, The George Junior Republic..., p. 117.

49 Ibidem, p. 118. 
the combination of a mother and a housekeeper. Her tasks were to supervise housemates, to keep the place tidy and clean and to give instructions. If minors caused any problems, the woman residing in the house concerned could order an unruly housemate to be transferred to another house. Conditions in houses depended on pupils' behaviour. If they behaved well, they could deserve a transfer to a better house with more comfortable beds or with a more diverse menu. However, conditions in all households did not go beyond Puritan principles followed by W.R. George. In one of his works, he wrote: 'A boy residing in the Republic village, who had a poor home or no home at all before he came to the community as a citizen, may occupy one of the finest cottages by virtue of his thrift, while the son of a millionaire may be in jail for vagrancy' ${ }^{50}$

The most important part of the social rehabilitation of minors in the Junior Republic was labour. Minors were employed mainly in farm works using, e.g., horses and two tractors. ${ }^{51}$ From time to time, graduates of agricultural faculties from local universities visited Freeville to teach farming to pupils. ${ }^{52}$ Methods of cultivation were so effective that later a very large percentage of minors worked on farms or had their own thriving farms. ${ }^{53}$ Apart from that, pupils performed gardening and woodworking. ${ }^{54}$ Particularly this second occupation was very valuable for the Junior Republic, because pupils engaging in this trade erected new buildings and made necessary repairs in rooms. ${ }^{55}$ Work in the printing house was also very popular. The printing house was adequately equipped, e.g., with printing presses, which allowed pupils to learn the secrets of the trade. Products were sold within the borders of the Junior Republic, and the name of the shop was The Franklin Print Shop. The quality

50 W.R. George, Nothing Without Labor..., p. 11.

51 W.R. George, The Junior Republic..., p. 156.

52 Idem, Nothing Without Labor..., p. 6.

53 Ibidem, p. 7.

54 To read more about the carpentry shop, see: Idem, The Junior Republic..., p. 219.

55 Idem, Nothing Without Labor..., p. 7. 
of the enterprise and products was so good that they were sold also in local towns and villages, and the earned funds were spent on the maintenance of the Junior Republic. ${ }^{56}$ In Freeville, there was also a bakery and a hydraulic plant, in which minors worked. They acquired the necessary skills that they could use in their adult life. Laziness or the improper performance of duties were not tolerated during work. This usually resulted in the loss of employment and funds indispensable to living in the Junior Republic. ${ }^{57}$

At this point, it is worth sketching a brief outline of the Junior Republic. The centre of the place was the shop in which goods produced by the children's community were sold. The shop was controlled entirely by minors, including salespersons. Their task was also to stimulate Freeville's economy by placing orders and making the community more active. ${ }^{5}$ Another significant place was the eatery, where minors also worked. They prepared meals by themselves and collected fees for them. The quality of meals is reflected best by the fact that W. R. George liked dining in the eatery run by his pupils. ${ }^{59}$ From among other important buildings erected by minors in Freeville, it is also worth mentioning the post office and the bank. Especially the second building played an important role, because it was responsible for issuing the currency used in the Junior Republic. ${ }^{60}$ Another important place in the Junior Republic was the school. However, it functioned differently from the then education system in the United States. Teachers focused mainly on stimulating their pupils' initiative rather than passing knowledge to them within the scope of particular subjects. The role of the teacher was, e.g., to suggest books in which pupils could find information about the topic of their interest. And if minors did not show any interest or passion, the role of the teacher was to find at least one occupation

\footnotetext{
56 Ibid.

57 T. Roosevelt, The George Junior Republic..., p. 117.

58 W.R. George, Nothing Without Labor..., p. 7.

${ }^{59}$ Z. Bugajski, The Junior Republic... (Republika dziecięca...), p. 9.

60 See: W.R. George, The Junior Republic..., p. 9.
} 
that would bring joy to the pupil. Not only the library, but also the theatre and the cinema served this purpose. ${ }^{61}$

Apart from labour and science, religion and sport also played a significant role in the Junior Republic. In Freeville, three religions existed on equal rights. Pupils were most often representatives of three leading religions: Catholicism, Protestantism and Judaism. ${ }^{62}$ All masses, irrespective of the religion, were said in the same chapel built by pupils. Although participation in masses was not compulsory, most minors used that privilege. Protestants and Catholics were the largest groups among pupils. ${ }^{63}$ The second element of impact on minors - sport - played an important part in the social rehabilitation of minors. They practised various sports, particularly basketball, football, tennis and baseball. Teams consisting of pupils of the Junior Republic competed very successfully with secondary school teams from local towns and villages. When Junior Republic teams played an away match, they were usually accompanied by a group of pupils supporting them on the stands. What W.R. George considered to be a sports success, was the fact that a few former pupils of the Junior Republic could subsequently boast good sporting achievements. They were, among others, players of university baseball teams, and two of them joined professional first-league clubs. ${ }^{64}$ Events enlivening the daily existence of minors were also held occasionally in the Junior Republic. There were dances and visits by family members and friends. ${ }^{65}$ Frequent contact between pupils and "normal society" became an idea that W.R. George cultivated. Its advantage was the minimised isolation of minors from life among other people.66 It is worth noting that arriving guests could visit Freeville without previous notice. It was humorously remarked that each person willing to visit the Junior Republic could spend

61 Ibid.

62 W.R. George, L.B. Stowe, Citizens Made and Remade..., p. 106.

63 T. Roosevelt, The George Junior Republic..., p. 118.

64 W.R. George, Nothing Without Labor..., p. 14.

65 W.R. George, L.B. Stowe, Citizens Made and Remade..., p. 240.

66 W.R. George, Nothing Without Labor..., p. 15. 
there: 'five minutes, five hours, five days, or as much longer as you desire' ${ }^{67}$

Subsequent lives of pupils were a measurable success of the Junior Republic. Research has shown that the institution was attended by future doctors, lawyers, engineers, civil servants, social workers, soldiers or professional baseball players. From among them, we can distinguish Harvey E. Miller - a lawyer and a candidate for the Congress from Cleveland, Arthur T. Baker - a member of the Democratic Party and a lieutenant of the US Army, Charles B. Dawson a journalist, or William F. McClelland - the principal of the state correctional school for boys in North Dakota.68 A large part of citizens of the Junior Republic enlisted in the army. According to data from the World War I period, as many as $87 \%$ of conscriptable pupils of the Junior Republic joined the US Army. At least several of them died in combat, fighting in the ranks of French, Canadian or American troops. One of the pupils wrote down his memories in the frequently reissued book $A$ Yankee in The Trenches. ${ }^{69}$ The moral stance of pupils during World War II was a pride both for the Junior Republic and for W.R. George himself. ${ }^{70}$ Their subsequent lives were evaluated for many years. They were contacted and received special questionnaires in which they specified the impact of the Junior Republic on their subsequent stances, and they were asked about their activity in adult life. One of them - the former president of the Junior Republic and a prosecutor in adult life - wrote: 'stimulated in me the desire to improve my mind and my desire and capacity for leadership. ... It made easy the transition from childhood and youth to the responsibilities of mature years' ${ }^{71}$ In another account written after many years by a boy coming from the lower social classes, we also read: 'mentally alert boys and girls, especially those surrounded by an environment tending toward the develop-

\footnotetext{
67 Ibidem, p. 41.

68 Ibidem, Nothing Without Labor..., pp. 36-37.

69 See: R.D. Holmes, Yankee in The Trenches, Fairfield 2005, p. 160.

70 W.R. George, Nothing Without Labor..., p. 34.

71 Ibidem, p. 35.
} 
ment of dangerous citizens... were taught knowledge, ways of earning money and respect for the authorities' ${ }^{72}$ The author of these words was the best example of this, because he finished legal studies at Ohio University and practiced as a lawyer in Cleveland. ${ }^{73}$

\section{Conclusion}

To sum up the activity of the Junior Republic, it is worth quoting T. Roosevelt's words - expressing his appreciation for work with minors in Freeville, he wrote: 'A boy who has gone wrong because he has too much steam in his boiler, so to speak, is admitted on a full equality with the boy who has never gone wrong at all; and the most extraordinary thing is that he is about as apt to turn out a first-class citizen, not merely of the Junior Republic, but of the larger republic, the republic of the American Nation, when he graduates into it'. ${ }^{\prime 4}$ The system introduced by W.R. George was based on Republican and democratic values, which were strongly rooted in the Americans' mentality. However, it was not free of faults and criticism. The strongest claim against W.R. George concerned the use of minors for labour and the favourable sale of products manufactured by pupils. ${ }^{75}$ It was also argued that the Junior Republic taught pupils only materialistic thinking, where money was the reward for each created good. This might result in the lack of social sensitivity in pupils and focusing only on economic goods in the future. ${ }^{76}$ Was this criticism justified? It seems that W.R. George's activity was one of many ways of coping with juvenile delinquency in the United States. The best answer to the above arguments is the fact that R.W. George's Junior Republic stood the test of time and

72 Ibidem, p. 38.

${ }^{73}$ Ibid.

${ }^{74}$ T. Roosevelt, The George Junior Republic..., p. 117.

75 The positive and negative arguments are discussed more broadly in J. Holl's work. See: J. Holl, Juvenile reform in the progressive era..., pp. 305-306.

${ }^{76}$ Z. Bugajski, The Junior Republic... (Republika dziecięca...), p. 9. 
exists in America until today. ${ }^{77}$ The founder of Freeville died in 1933, leaving not only lasting achievements in the form of the idea of the Junior Republic and its activity. In the subsequent period of his life, he also disseminated knowledge about working with minors. He published a number of books in which he presented his views on the education of juvenile offenders. ${ }^{78}$ Upon his visit to Freeville in the early $20^{\text {th }}$ century, the US President Theodore Roosevelt called the Junior Republic 'a manufactory of good citizens' ${ }^{79}$

\section{References}

Adams J., Woman \& The Vote - A World History, Oxford 2014.

Baley S., Zagadnienie walki z przestępczościa młodocianych na tle wspótczesnych doświadczen w Stanach Zjednoczonych Ameryki Pótnocnej, Warszawa 1948.

Barczykowska A., Dzierzyńska-Breś S., Resocjalizacja nieletnich w Stanach Zjednoczonych Ameryki, "Resocjalizacja Polska” 2015, no. 9.

Barczykowska A., Dzierzyńska-Brześ S., Muskała M., System oddziaływań resocjalizacyjnych Anglii i Stanów Zjednoczonych Ameryki, Poznań 2016.

Blackstone W., Law and Letters in the Eighteenth Century, Oxford 2008.

Bugajski Z., Nieletni w świetle obowiazujących ustaw karnych w Polsce, "W Służbie Penitencjarnej", 1936, no. 3

Bugajski Z., Republika dziecięca, "W Służbie Penitencjarnej” 1936, no. 14.

Canfield M. R., Roosevelt in The Field, Chicago 2015.

Constitution and the General Laws of the George Junior Republic Freeville N.Y., New York 1922.

Czapów C., Czy Johnny stanie się gangsterem. Uwagi o metodach walki z przestępczościa młodzieży, Warszawa 1959.

Ćmiel S.. Przestępczość nieletnich - teoria i praktyka, Józefów 2011.

Dukaczewski E.J., Rys historyczny rozwoju opieki nad dzieckiem niedostosowanym spotecznie (przestępczym) w Polsce do wybuchu II wojny światowej, [in:] Resocjalizacja nieletnich. Doświadczenia i koncepcje, pod red. K. Pospiszyl, Warszawa 1990.

Fish H., Nasze więziennictwo dla nieletnich, "Przegląd Więziennictwa Polskiego", 1935, no. 2.

Funk \& Wagnalls Standard Encyclopedia of the World's Knowledge, New York 1912.

77 See: https://gir.org/ (access: $4^{\text {th }}$ June 2020).

78 See: W.R. George, The Adult Minor, New York 1937, pp. 192.

${ }^{79}$ T. Roosevelt, The George Junior Republic..., p. 118. 
George W.R., Nothing Without Labor: being the motto of the Gorge Junior Republic located at Freeville New York, New York 1922.

George W.R., Stowe L.B., Citizens Made and Remade, New York - Boston, 1912.

George W.R., The Adult Minor, New York 1937.

George W.R., The Junior Republic History and Ideals, New York 1910.

Golus A., Plagi, dyby, kajdany, czyli jak naprawiano młodzież: historia społeczna, "Ale historia", 2017, no. 35.

Grzegorzewska M., Wychowanie nieletnich przestępców, "Przegląd Więziennictwa Polskiego", 1929, no 10.

Popławski H., Prawo Penitencjarne, Gdańsk 1984.

Holl J.M., Juvenile reform in the progressive era: William R. George and the Junior Republic movement, Ithaca 1971.

Holmes D.R., Yankee in The Trenches, Fairfield 2005.

Hull W., The George Junior Republic, "Annals of the American Academy of Political and Social Science", 1897, v. 10.

John Locke Prophet of Common Sense, New York 1967.

Kaczyńska W., Czesław Czapów 1925-1980. Świadectwo trzech pokoleń, Warszawa 2003.

Kołakowski A., Problematyka przestępczości nieletnich w międzywojennej Polsce na łamach "Przegladu Więziennictwa Polskiego", "Prace Naukowe Akademii im. Jana Długosza w Częstochowie, 2017, v. 26, no. 2.

Kosnarewicz E., Stefan Baley, [in:] Stownik psychologów polskich, ed. Rzepa T., Stachowski R., Poznań 1992.

Kułan B., Edukacja jako forma resocjalizacji nieletnich przestępców w II Rzeczypospolitej, [in:] Wybrane obszary wychowania $i$ edukacji dziecka w ujęciu historycznym, ed. B.A. Orłowska, B.M. Uchto-Żywica, K. Prętki, Gorzów Wielkopolski 2019.

Kułan B., Nieznana ofiara Katynia. Zygmunt Bugajski (1887-1940) prawnik i penitencjarysta, Kraków 2018.

Mazur J.A., Opieka i resocjalizacja wobec przestępczości nieletnich w okresie międzywojennym na przykładzie Lublina, Kraków 2017.

Mogilnicki A., Dziecko i przestępstwo, Warszawa 1925.

Montesquieu C., O duchu praw, Warszawa 2009.

Morris E., The Rise of Theodore Roosevelt, Chicago 2001.

Neymark E., Nieletni przestepcy w Polsce, "Gazeta Administracji i Policji Państwowej", 1924, no. 11.

Raś D., O poprawie winowajców więzieniach i zakładach dla nieletnich, Katowice 2006.

Reynolds C.R., Fletcher-Janzen E., Concise Encyclopedia of Special Education, New York 2002.

Roosevelt T., The George Junior Republic, “The Outlook”, 1912, v. 100.

Rousseau J.J., Emili - czyli o wychowaniu, v. 1-2, Warszawa 1955.

Sokołowski S., Zakłady poprawcze dla nieletnich, "Przegląd Więziennictwa Polskiego", 1933, no. 1. 
Walczak S., Prawo penitencjarne, Warszawa 1972.

Zawadzka S.E., Jan Jakub Rousseau, Warszawa 2009.

Websites

https:/ / freshair.org/learn-about-us/ (access: $4^{\text {th }}$ June 2020) https://gir.org/ (access: $4^{\text {th }}$ June 2020) 